\title{
Orthodontic-surgical treatment of a patient with Marfan Syndrome and Obstructive Sleep Apnea Syndrome: a case report with a 9-year follow-up
}

\author{
Tratamento ortodôntico-cirúrgico de um paciente com Sindrome \\ de Marfan e Sindrome da Apnéia Obstrutiva do Sono: relato \\ de caso com 9 anos de acompanhamento
}

Willian Caetano RODRIGUES ${ }^{1}$ iD $0000-0002-3616-1071$
Mário Francisco Real GABRIELLI ${ }^{1}$ iD $0000-0002-7636-8069$
Marina Reis OLIVEIRA ${ }^{1}$ iD $0000-0002-1952-0730$
Ana Cláudia Gabrielli PIVETA ${ }^{2}$ iD $0000-0001-9802-0023$
Marisa Aparecida Cabrini GABRIELLI ${ }^{1 \text { iD }} 0000-0002-7147-1438$

\section{ABSTRACT}

Marfan's (MFS) syndrome is characterized by a defect in the connective tissue, which affects multiple organic systems. Therefore, the management of these patients requires a multidisciplinary approach. This case reports the orthodontic-surgical treatment of a patient who presented both Marfan's and obstructive sleep apnea syndrome. Patient had malocclusion, TMJ clicking, vertical maxillary excess, mandibular retrognathia, severe esthetic compromise, signs and symptoms of obstructive sleep apnea syndrome, as well as alterations in joints, cardiovascular and respiratory systems. He was treated with bimaxillary surgery aimed to enhance esthetics, occlusion and address the obstructive sleep apnea syndrome. The clinical results show that a desirable functional occlusion was achieved and both patient's facial esthetics and quality of life were significantly improved. After a 9-year follow-up period, these pleasing features were maintained. The diagnosis and management of Marfan's patients is challenging and require multidisciplinary follow-up.

Indexing terms: Marfan's syndrome. Obstructive sleep apnea syndrome. Orthognathic surgery.

\section{RESUMO}

A sindrome de Marfan (SMF) é caracterizada por um defeito no tecido conjuntivo que afeta múltiplos sistemas orgânicos. Portanto, o manejo desses pacientes requer uma abordagem multidisciplinar. Este artigo relata o tratamento ortodôntico-cirúrgico de um paciente

1 Universidade Estadual Paulista "Júlio de Mesquita Filho", Faculdade de Odontologia de Araraquara, Departamento de Diagnóstico e Cirurgia. Endereço: Rua Humaitá, 1680, Centro, 14801-385, Araraquara, SP, Brasil. Correspondência para / Correspondence to: WC Rodrigues. E-mail: <ortowill@yahoo.com.br>.

2 Universidade Estadual Paulista "Júlio de Mesquita Filho", Faculdade de Odontologia de Araraquara, Departamento de Odontologia Social. Endereço: Rua Humaitá, 1680, Centro, CEP: 14801-385, Araraquara, SP, Brasil. E-mail: acgp@foar.unesp.br

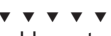

How to cite this article

Rodrigues WC, Gabrielli MFR, Oliveira MR, Piveta ACG, Gabrielli MAC. Orthodontic-surgical treatment of a patient with Marfan Syndrome and Obstructive Sleep Apnea Syndrome: a case report with a 9-year follow-up. RGO, Rev Gaúch Odontol. 2019;67:e20190050. http://dx.doi. org/10.1590/1981-863720190005020180013 
com síndrome de Marfan e síndrome da apneia obstrutiva do sono (SAOS). Ele manifestava má oclusão, estalidos na ATM, excesso vertical de maxila, retrognatismo mandibular, comprometimento estético severo, sinais e sintomas de síndrome da apneia obstrutiva do sono, além de alterações nas articulações, nos sistemas cardiovascular e respiratório. O tratamento incluiu cirurgia bimaxilar com o objetivo de melhorar a estética, a oclusão e tratar sua apneia obstrutiva do sono. Os resultados clínicos mostram que uma oclusão funcional desejável foi alcançada e tanto a estética facial quanto a qualidade de vida do paciente foram significativamente melhoradas. Após um período de 9 anos de acompanhamento, essas características agradáveis foram mantidas. O diagnóstico e tratamento de pacientes com síndrome de Marfan é desafiador e requer acompanhamento multidisciplinar.

Termos de indexação: Síndrome de Marfan. Síndrome da apneia obstrutiva do sono. Cirurgia ortognática.

\section{INTRODUCTION}

Marfan Syndrome (MFS) is an inherited disorder characterized by an imperfection in the connective tissue due to poor processing of fibrillin-1, a glycoprotein essential for the production of elastic fibers, resulting in tissue laxity, which can mainly affect the cardiovascular, musculoskeletal and ocular systems, as well as skin, dura mater and respiratory systems [1-5]. Clinically, the patients may have high stature relative to age, scoliosis, excessive bone growth, dolichostenomelia, arachnodactyly, hypermobile joints, increased skin elasticity, myopia, and lens luxations [2-6]. Craniofacial abnormalities include elongated and narrow face (dolichocephaly), enophthalmos, retrognathism and mandibular hypoplasia, protruding bosses and supraorbital processes, increased intercanthal distance, capsule sagging and temporomandibular joint ligaments and frequent gingivitis [7-9]. Breathing is predominantly buccal, which results in ogival and deep palate, maxillary atresia, dental crowding and malocclusion [10-12]. Cystic lesions, bifid uvula and cleft palate may also be present [13].

Although a small number of cases are linked to mutation in the transforming growth factor receptor-2 (TGFR2) gene $[11,12]$, the classical form of MFS is most commonly caused by FBN1 gene mutation located on chromosome 15 (q21.1) [3]. The defective gene has high penetrance, autosomal dominant transmission, variable intra- and inter-family expressivity, no predilection for race or gender, and estimated prevalence ranging from $1 / 5,000$ to $1 / 10,000$ live births $[5,14]$. In about $75 \%$ of cases, such character is inherited and, in the other $25 \%$, the defect results from a new mutation [15]. The disease shows surprising pleiotropism and clinical variability, frequently overlapping signs and symptoms with other connective tissue disorders, such as Loeys-Dietz syndrome, Shprintzen-Goldberg syndrome, and the vascular form of Ehlers-Danlos syndrome $[5,12,16]$.

Obstructive Sleep Apnea Syndrome (OSAS), on the other hand, is characterized by several signs and symptoms, such as loud and disturbing snoring, respiratory pauses during sleep, daytime hypersomnolence, deterioration of quality of life, impairment of cognitive functions, irritability and anxiety. Patients experience recurrent events of partial or complete obstruction of the pharyngeal airway during sleep, despite the maintenance of inspiratory efforts. Reduction (hypopnea) or complete cessation (apnea) of the airflow leads to hypoxemia and hypercapnia, which induces several awakenings during sleep to reestablish the patency of the upper airway $[17,18]$.

Among the predisposing factors for OSAS, we can highlight craniofacial abnormalities, such as hypoplasia/ maxillomandibular retrusion, increased amount of soft tissues and/or lymphoid tissue in the pharynx, nasal obstructions, hypothyroidism, acromegaly, and diminished action of pharyngeal dilator muscles. It is, therefore, a condition associated with a greater tendency to the collapse of the upper airways [10,19-22].

The objective of this case report is to discuss the difficulties in the diagnosis and management of patients with Marfan Syndrome, including orthodontic-surgical approach, as well as to highlight the clinical aspects that require multidisciplinary follow-up.

\section{CASE REPORT}

This is the case of J.S.C.T. an 18-year-old patient, previously diagnosed with Marfan Syndrome, who sought treatment for dental-skeletal deformity, with complaints related to dental malocclusion, cracking at the temporomandibular joint (TMJ) and severe aesthetic impairment due to the excessive gingival exposure and retrognathism. The patient was already undergoing orthodontic treatment and was referred by the professional in charge.

During the anamnesis, the patient reported diurnal fatigue and excessive daytime somnolence, 
concentration difficulties, snoring and restless sleep. Previous medical history included frequent problems in the respiratory tract of rhinitis, sinusitis, bronchitis, and eight episodes of pneumonia. He also reported, sporadically, edema in the joints. The patient was then followed up by a multidisciplinary team including otorhinolaryngologist, cardiologist, pulmonologist and physiotherapist.

Approximately two years before this first evaluation, the patient was diagnosed with OSAS (moderate degree), proven by polysomnographic examination $(\mathrm{AHI}=20$ events/hour). At the time, as a therapeutic measure, the patient underwent surgical procedures of turbinectomy, adenoidectomy, uvulopalatopharyngoplasty and correction of nasal septum deviation; however, without considerable improvement. One year later, a mitral valve prolapse was confirmed and the diagnosis of MFS was confirmed by the geneticist.

In the service of oral and maxillofacial surgery, physical examination showed the following (figure 1): longilineous biotype, with moderate kyphosis and scoliosis and propelled shoulders; vertical maxillary excess; $4.5 \mathrm{~mm}$ gingival exposure in the spontaneous smile and $9 \mathrm{~mm}$ in the forced smile; hyperdivergent pattern with tendency to open skeletal bite; increased lower third of the face; incomplete labial sealing (lip incompetence); retrognathism and mandibular hypoplasia, characterizing a skeletal Class II; convex profile with decreased chin-neck distance; temporomandibular joint disorder (TMD), with bilateral click and anterior disc displacement, without reduction, on the left side, with consequent deviation during mouth opening; mild anterior lower dental crowding and upper dental midline deviation to the right.

Considering the magnitude of the aesthetic complaint and the evidence that OSAS may worsen the cardiovascular prognosis of patients with MFS, we planned to carry out an orthognathic surgery, in order to provide a volumetric increase of the upper airway, correction of the facial deformity and occlusion. In this case, Cefazolin was used for prophylaxis against bacterial endocarditis. The surgical procedure was bimaxilar, with anterior impaction

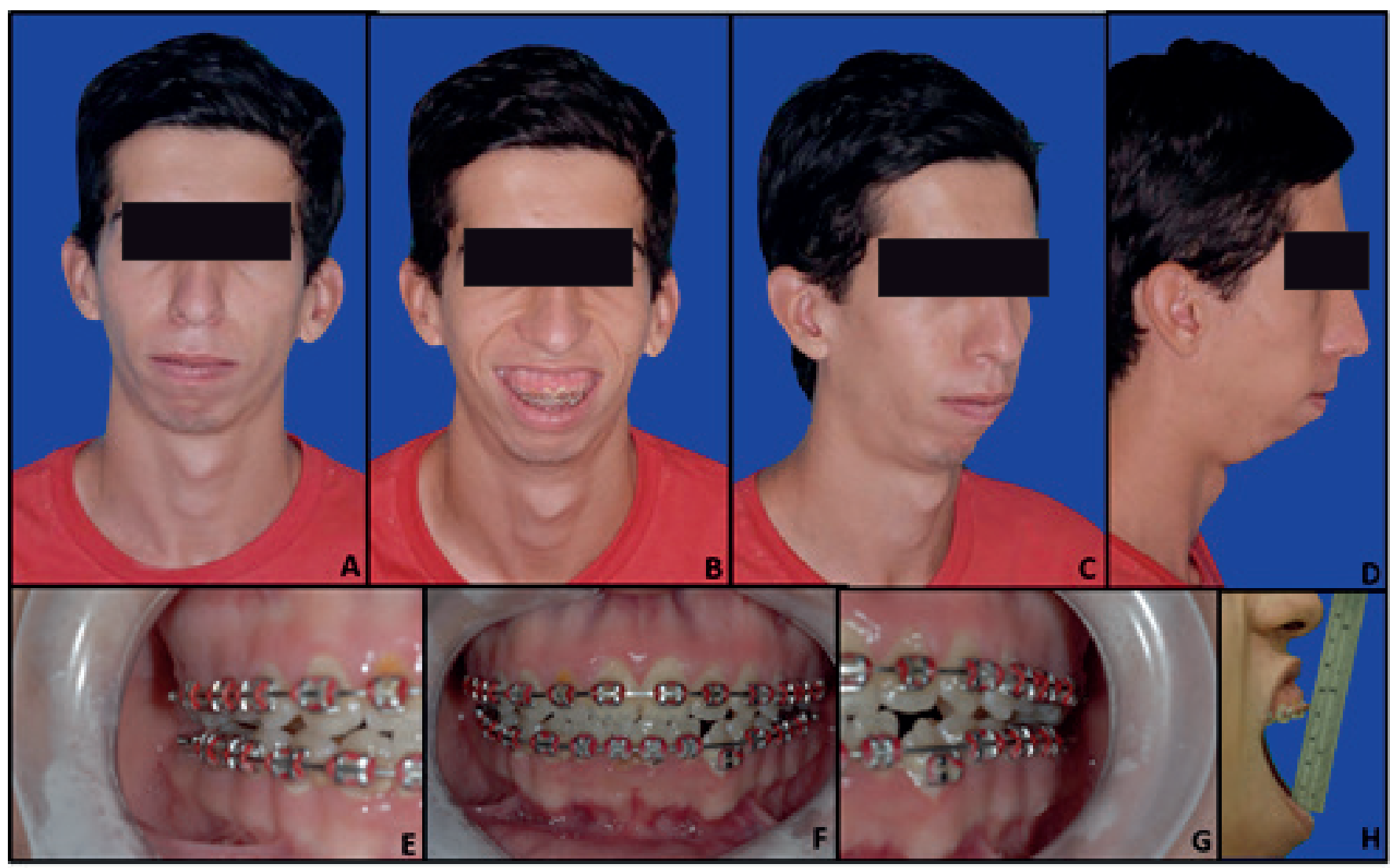

Figure 1. Class II type skeletal deformity with vertical excess of the patient with Marfan's Syndrome. 
of the maxilla and counterclockwise rotation of the occlusal plane, mandibular advancement with counter-clockwise rotation and mentoplasty for advancement. However, due to orthodontic problems, in order to better position the left lower canine in the arch, there was occlusal recurrence, requiring a new mandibular surgical repositioning. In the same approach, a new mentoplasty was performed. From the airway point of view, profile radiography suggests an increase smaller than that expected for the procedure (figure 2).

Eleven months after the first surgical approach, the patient presented improvement in the quality of life, with reduced fatigue and diurnal somnolence. A new polysomnographic examination (PSG) evidenced $\mathrm{AHI}=10$ events/hour. However, although the patient maintained the improvement in OSAS symptoms, three years and eleven months after surgery, a new polysomnography showed $\mathrm{AHI}=19$ events/hour. From the occlusal, aesthetic and stomatognathic point of view, 9 years postoperatively, the result was the one predicted (figure 3 ). Figure 4 compares the pre- and post-operative profiles.
The patient signed an informed consent form in which he authorized the use and publication of data and images related to his treatment for scientific purposes.

\section{DISCUSSION}

Due to the highly variable presentation of affected subjects, the age-dependent nature of many of their clinical manifestations and their extensive differential diagnosis, the diagnostic evaluation of MFS is quite complex [23]. For this reason, in 1986 an international panel of experts defined a set of clinical criteria (Berlin Nosology) for a more accurate diagnosis of MFS. The objective was to facilitate accurate communication about this condition among health professionals, researchers and patients, allowing a more adequate management and more effective counseling to patients with this syndrome [24].

In 1991, with the evidence that a mutation in the FBN1 gene, encoder of the fibrillin-1 protein, would be the main causative agent of MFS [3], it was recognized that Berlin Nosology had limitations. In 1996, new diagnostic criteria were presented and referred to as the Ghent

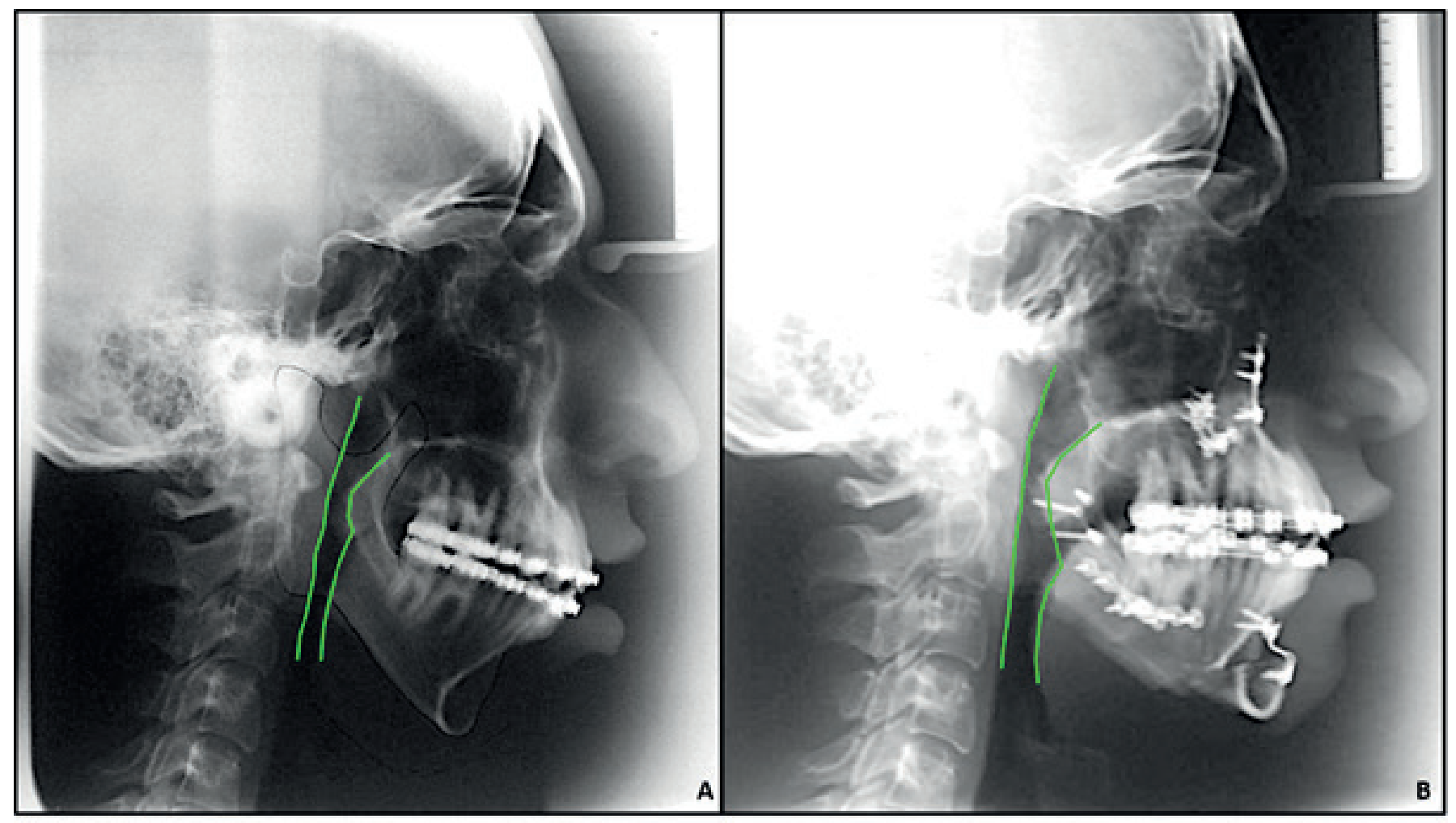

Figure 2. Radiographic images comparing an smaller increase in the airway after orthognathic surgery. 


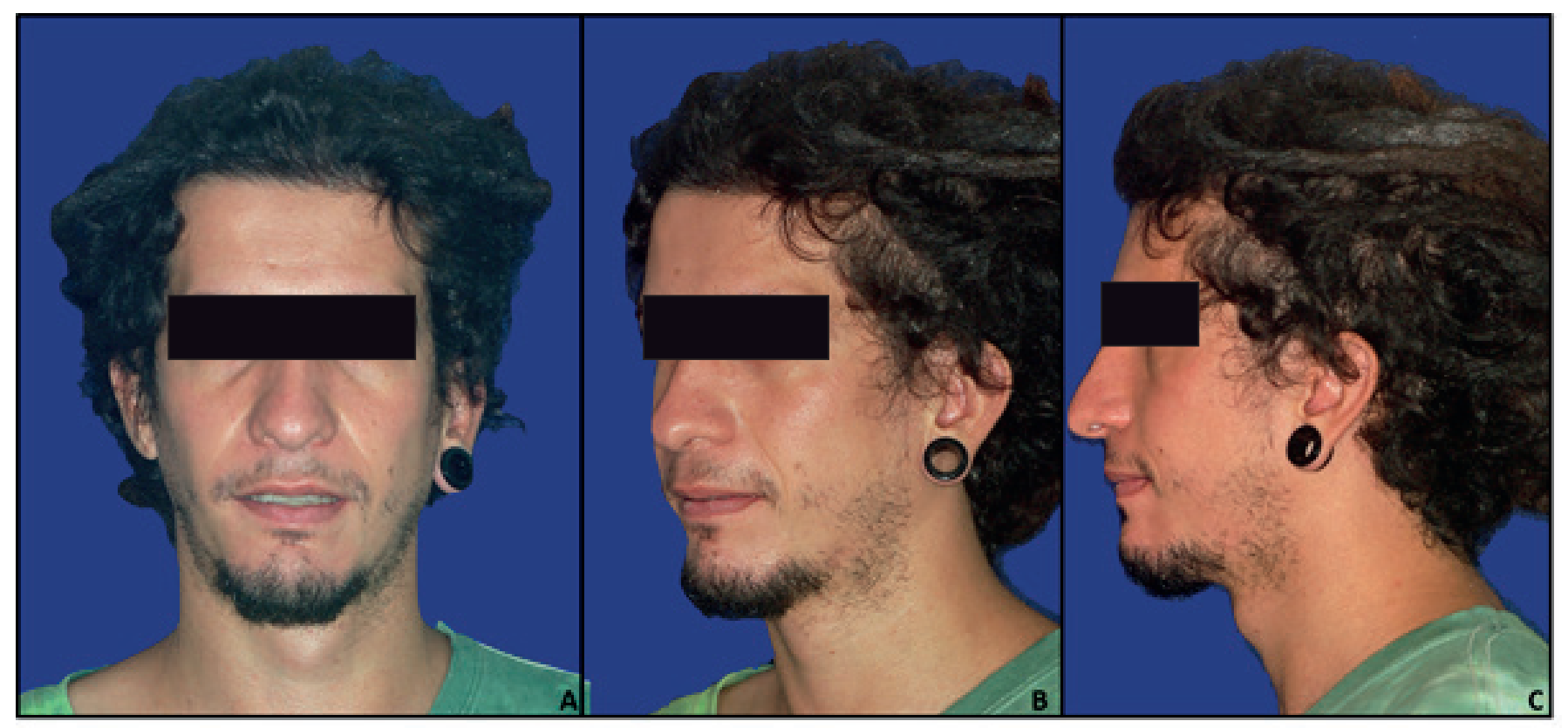

Figure 3. 9-year postoperative period of correction of skeletal deformity.

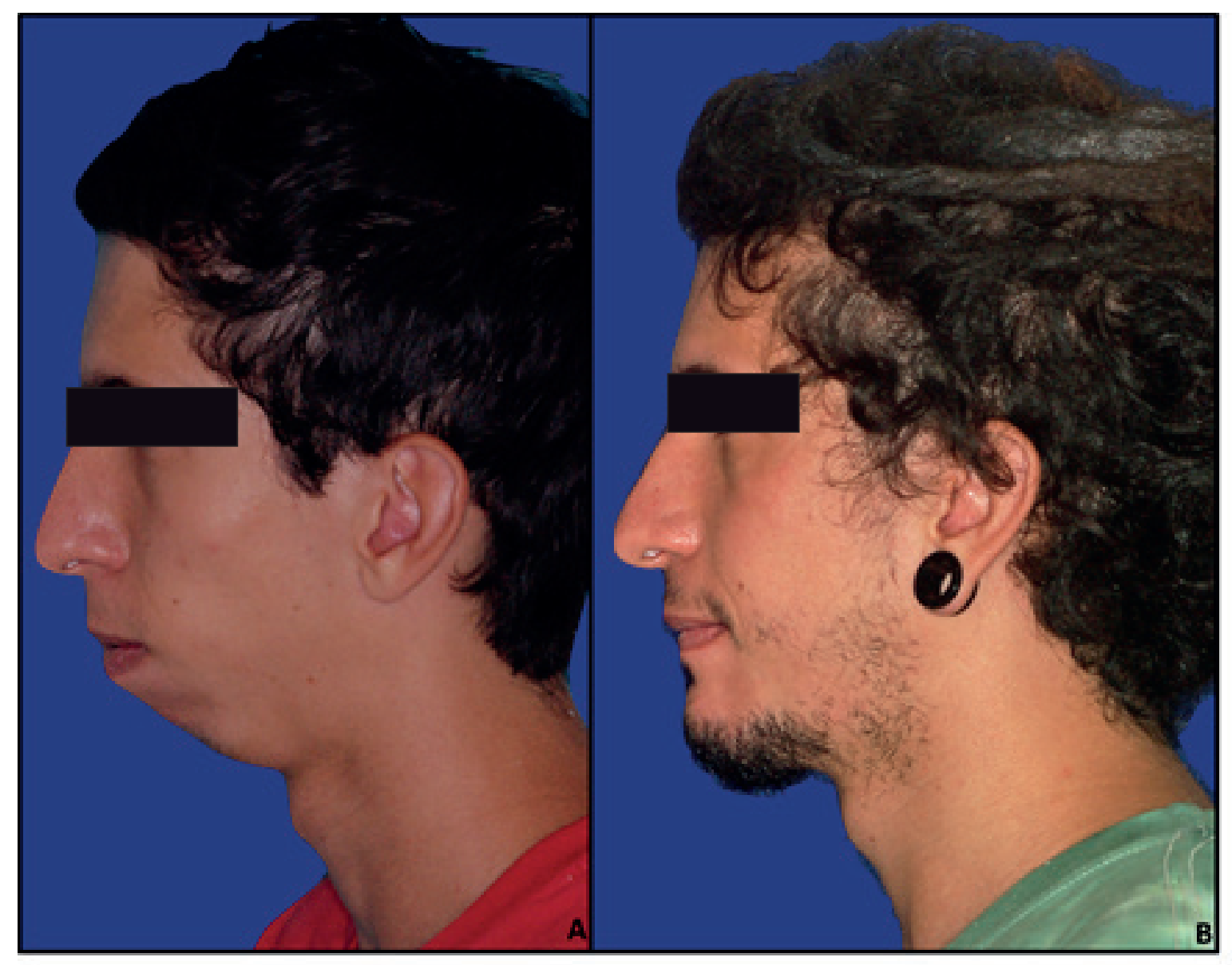

Figure 4. Pre and postoperative profiles. 
Nosology. According to these guidelines, the diagnosis should be based on the family history and the combination of clinical manifestations in different organ systems, which are assigned a higher or lower diagnostic specificity [25].

The Ghent criteria became widespread worldwide and were subsequently revised in order to increase their accuracy and specificity [16]. Greater importance was given to two cardinal features of the syndrome, aneurysm/ dissection of the aortic root and ectopia of the lens. All other cardiovascular and ocular manifestations, as well as findings in other organ systems such as skeleton, dura mater, skin and lungs, contribute to a "systemic score" that guides the diagnosis when aortic disease is present, except for the ectopy of the lens. A more prominent role has been attributed to the molecular genetic test of FBN1 and other relevant genes, although it is not a formal requirement, since the tests still do not have $100 \%$ sensitivity and specificity and impose financial burdens that make them unviable in some countries. Considerations and additional tests are needed if a patient also shows unexpected signs, particularly if they are suggestive of a specific alternative diagnosis, such as other syndromes [16].

Specifically in the case of the presented patient, the diagnosis of MFS was established by the confirmation of mutation in the FBN1 gene, associated with a systemic score $\geq 7$ while the patient was still under 20 years old. In spite of the very characteristic set of signs and symptoms of OSAS presented by the patient, the definitive diagnosis required a complete PSG, which showed a moderate degree of the syndrome ( $\mathrm{AHI}=20$ events/hour). At the same time, the pulmonologist requested a pulmonary function test that showed a reduction in the Forced Vital Capacity (FVC), characterizing a marked reduction in pulmonary volumes, despite the relatively low level of scoliosis $\left(10^{\circ}\right)$. Patients with MFS usually are more prone to pulmonary complications, including restrictive ventilatory defects, bullous emphysema and increased pneumothorax frequency. These abnormalities should be detected and monitored before worsening [26].

The high prevalence of OSAS in patients with MFS, already well established in the literature, may be justified by the high resistance of the nasal airways, probably mediated by maxillary constriction and arched palate, and involvement of the pharynx by the characteristic connective tissue defect in patients with MFS, making it more collapsible during sleep $[10,19,22]$. It is noteworthy that the degree of collapsibility observed in high and lean marfanoid patients is greater than that observed previously in typically obese patients with more severe forms of OSAS [10].

The identification of any treatable risk factor for cardiovascular complications in patients with MFS is of great clinical and scientific interest. Since OSAS is associated with profound hemodynamic changes, in the short and long term, it is possible that its coexistence in patients with MFS has deleterious effects, particularly with regard to aortic root dilatation $[18,21]$. The possible underlying pathophysiological mechanisms are postapnea reflex sympathetic activation and consequent marked increases in diurnal blood pressure, as well as obstructive apneas involving repeated inspiratory effort against collapsed upper airways, causing subatmospheric intrathoracic pressure events (sometimes less than 60 $\mathrm{mm} \mathrm{Hg}$ ) and producing extensive shear stresses in the intrathoracic structures, including the ascending aorta [21]. Early diagnosis is essential for the implementation of pharmacological protection for the aortic wall, maintaining blood pressure at normal levels and reducing pulsatile flow, which may delay the development of severe aneurysmal dilatation and aortic rupture $[21,22]$.

The gold standard for clinical management of OSAS in adult patients is the use of CPAP (Continuous Positive Airway Pressure) [18]. However, the patient's relatives could not invest in the equipment and, as an alternative, the otolaryngologist who followed up him at the time performed surgical procedures generally referred to as "Stanford Phase I Interventions" (PI), which aimed to reduce soft tissue volume in the rhino-oro-hypopharynx, maintaining intact the skeletal framework [27]. The results were not satisfactory, as the symptoms remained practically unchanged. In fact, the efficacy of procedures involving only the soft tissues (PI) for the treatment of OSAS, such as uvulopalatopharyngoplasty, has been questioned since the 1990s, when it was evidenced that the success rate varies only from 24 to $48 \%[27,28]$. On the other hand, extensive uvulopalatopharyngoplasty procedures may make it difficult to perform maxillomandibular advancement, in the sense of potential predisposition for velopharyngeal incompetence in large maxillary advancements [28].

Orthognathic surgery for maxillomandibular advancement, eventually referred to as Stanford Phase II surgery, when focused on the treatment of OSAS $[27,28]$, previously pulls all soft tissue adhered to the maxilla and mandible, including part of the pharyngeal musculature, 
palatine veil, tongue and buccal floor muscles, in addition to subcutaneous tissue. In theory, this protraction should increase the volume capacity of the upper airway, increasing its permeability during sleep [29]. In fact, the current surgical planning for surgical treatment of obstructive sleep apnea should be conducted in a multilevel fashion, so that all predisposing factors of the obstruction diagnosed (nasal, pharyngeal and skeletal) are treated with a single or staged procedure, as the case may be.

However, the patient had limitations in facial aesthetics and orthodontic preparation that made a maxillary advancement as extensive as that proposed in the literature $( \pm 10 \mathrm{~mm})$ impossible for the treatment of OSAS $[27,28]$. Therefore, the maxilla received mainly anterior impaction, with little maxillary bone advancement and mainly dental advancement, but allowing anti-clockwise rotation of the mandible with significant advancement of the pogonium. The other option would have been to alter the preoperative orthodontic preparation, with premolar extraction, which would allow a greater advancement of the maxilla associated with impaction, by correcting the inclination of the upper incisors, with the consequent greater advancement of the mandible. For reasons related to the patient and the institution where the patient underwent the orthodontic preparation, this was not possible.

The radiographic image of the cavum performed postoperatively showed a smaller-than-expected airspace alteration, despite the significant mandibular advancement. It is possible that the MFS characteristics change the relationship between bone advancement and increased airway dimensions by soft tissue traction, when compared to non-syndromic patients. The new PSG showed a reduction of $50 \%$ in $\mathrm{AHI}$ and the patient experienced resolution of the signs and symptoms of apnea, which could be considered a clinical success. The patient reported improvement in the quality of life, with reduction of daytime hypersomnia. This may also be related to more subjective factors, such as satisfaction with the aesthetic benefit obtained and the social impact of facial changes [26].

Patients with MFS are more prone to recurrence after orthodontic treatment, orthopedic facial treatment or even orthognathic surgery $[8,11]$. This is probably related to the laxity (sagging) of the connective tissue, characteristic of the syndrome $[10,11,23]$ and the narrowing of the nasal airway and consequent increased resistance to airflow in this region, which force the patient to a compensatory predominant mouth breathing. This affects the natural posture of the head $[7,10,12]$ causing the tongue to remain most of the time slightly protruded and the teeth disoccluded, which also contributes to the elongation of the lower third of the face and treatment relapse $[11,27]$.

Generalized joint hypermobility, signs and symptoms of subluxation of TMJ and anterior disc displacement are frequent clinical findings in MFS $[7,8,11,23]$. The prevalence of subjective complaints of TMD in MFS was examined by Westling et al. [7] in 76 patients. Among the subjects interviewed in this study, $56 \%$ indicated dysfunctions and/or pain in the TMJ region and 25\% were undergoing treatment for these symptoms. A study conducted in Germany involving 350 patients with MFS showed prevalence of TMJ subluxation symptoms (25\%) well above the frequency reported in previous studies in normal populations ( $2 \%$ to $3 \%$ ). This can be explained by the hypermobility of the articular disc and the TMJ itself, caused by connective tissue disorders in MFS [30]. These data support the theory that, in addition to occlusal, psychological and parafunctional factors, constitutional factors, such as general connective tissue disorders, also represent an important factor in the onset of TMJ dysfunction [30]. In the case of the concerned patient, the anterior disc displacement was not treated, but this did not result in functional problems or long-term painful symptomatology.

Indications for orthodontic treatment are more frequent in the MFS population than in non-syndromic subjects, because intraoral alterations such as maxillary atresia associated with posterior crossbite, severe dental crowding, skeletal anterior open bite and gingival smile, are closely related to MFS $[7,8,11]$. Often, patients whose syndromic condition was not previously diagnosed may seek treatment, and the orthodontist may then collaborate for the diagnosis at an early age. For the oral and maxillofacial surgeon, the challenge of performing orthognathic surgery lies mainly in the limitations imposed by the various systemic manifestations of the syndrome, especially the cardiovascular ones, in addition to the recurrence rates [11].

The goals of dental treatment in individuals with MFS do not differ from those in healthy patients. However, some particularities must be observed. For example, when there are cardiac or aortic valve abnormalities, prophylactic antibiotics may be necessary prior to any surgical procedure 
or any intervention that may lead to minimal bleeding, including dental cleaning, root scaling and straightening, or even orthodontic bandage $[8,15]$. On the other hand, cardiovascular changes, including aortic and pulmonary changes, in extreme cases, may contraindicate the surgical procedure [15]. In this patient, specifically, during the course of the treatment, there were occasional bouts of dyspnea, which were attributed to pulmonary and cardiovascular causes by the attending professionals. It should be noted that, in this patient, $\mathrm{AHI}$ returned to preoperative levels 19 months postoperatively, despite the improvement of signs and symptoms, which suggests that the recurrence rates of the respiratory problem in patients with MFS may be higher than expected in non-syndromic patients.

Finally, the clinical results showed that patient's facial esthetics were significantly improved and a desirable functional occlusion was achieved. After a 9-year followup period, these pleasing features were maintained.

\section{CONCLUSION}

The diagnosis of MFS is quite complex and involves a set of clinical manifestations in different organ systems. Plenty of them can be detected during routine treatments by orthodontists, general practitioners or oral and maxillofacial surgeons. Facial deformities and OSAS are among the most important highlights of interest in dentistry. The management of these patients is challenging and require multidisciplinary follow-up.

\section{Collaborators}

WC RODRIGUES and MR OLIVEIRA, writing of the manuscript. MFR GABRIELLI, surgical procedure and case documentation. ACG PIVETA, helping in the case documentation and literature review. MAC GABRIELLI, critical review of the $m$ English version.

\section{REFERENCES}

1. DelloStritto R, Branham S, Chemmachel C, Patel J, Skolkin D, Gilani S, et al. Importance of early detection and cardiovascular surgical intervention in Marfan Syndrome. Adv Emerg Nurs J. 2017;39(3):217-223. http://dx.doi.org/10.1097/TME.0000 000000000153

2. Grewal N, Gittenberger-de Groot AC. Pathogenesis of aortic wall complications in Marfan syndrome. Cardiovasc Pathol.
2018;33:62-69. http://dx.doi.org/10.1016/j.carpath.2018.01. 005

3. Sakai LY, Keene DR, Renard M, De Backer J. FBN1: The disease-causing gene for Marfan syndrome and other genetic disorders. Gene. 2016;591(1):279-291. http://dx.doi. org/10.1016/j.gene.2016.07.033

4. Aubart M, Gross MS, Hanna N, Zabot MT, Sznajder M, Detaint $D$, et al. The clinical presentation of Marfan syndrome is modulated by expression of wildtype FBN1 allele. Hum Mol Genet. 2015(10);24:2764-70. http://dx.doi.org/10.1093/hmg/ ddv037

5. Faivre L, Collod-Beroud G, Loeys BL, Child A, Binquet C, Gautier $E$, et al. Effect of mutation type and location on clinical outcome in 1013 probands with Marfan syndrome or related phenotypes and FBN1 mutations: an international study. Am J Hum Genet. 2007;81(3):454-66. http://dx.doi. org/10.1086/520125

6. Keene DR, Maddox K, Kuo H, Sakai LY, Glanville RW. Extraction of extendible beaded structures and identification as fibrillin-containing extracellular matrix microfibrils. J Histochem Cytochem. 1991;39(4):441-449. http://dx.doi. org/10.1177/39.4.2005373

7. Westling L, Mohlin B, Bresin A. Craniofacial manifestations in the Marfan syndrome: palatal dimensions and a comparative cephalometric analysis. J Craniofac Genet Dev Biol. 1998; 18:211-8.

8. De Coster PJ, Martens LC, De Paepe A. Oral manifestations of patients with Marfan syndrome: a case-control study. Oral Surg Oral Med Oral Pathol Oral Radiol Endod. 2002;93(5):564572. http://dx.doi.org/10.1067/moe.2002.121430

9. De Coster PJ, Martens LC, De Paepe A. Orofacial manifestations of congenital fibrillin deficiency: pathogenesis and clinical diagnostics. Pediatr Dent. 2004;26:535-7.

10. Cistulli PA, Sullivan CE. Influence of maxillary morphology on nasal airway resistance in Marfan's syndrome. Acta Otolaryngol. 2000;120(3):410-3. http://dx.doi.org/10.1080/0 00164800750000658

11. Utreja A, Evans CA. Marfan syndrome-an orthodontic perspective. Angle Orthod. 2009;79(3):394-400. http://dx. doi.org/10.2319/112707-558.1

12. Docimo R, Maturo P, D'Auria F, Grego S, Costacurta M, Perugia $C$, et al. Association between oro-facial defects and systemic alterations in children affected by Marfan Syndrome. J Clin Diagn Res. 2013;79(4):700-3. http://dx.doi.org/10.7860/JCD $R / 2013 / 5656.2885$

13. De Coster P, De Pauw G, Martens L, De Paepe A. Craniofacial structure in Marfan syndrome: a cephalometric study. Am J Med Genet A. 2004;131(3):240-8. http://dx.doi.org/10.1002/ ajmg.a.30393

14. Groth KA, Hove H, Kyhl K, Folkestad L, Gaustadnes M, Vejlstrup $N$, et al. Prevalence, incidence, and age at diagnosis in Marfan Syndrome. Orphanet J Rare Dis. 2015;10: 3-10. http://dx.doi.org/10.1186/s13023-015-0369-8

15. von Kodolitsch $Y$, Rybczynski M, Vogler M, Mir TS, Schüler $H$, Kutsche $K$, et al. The role of the multidisciplinary health care team in the management of patients with Marfan 
syndrome. J Multidiscip Healthc. 2016;9:587-614. http://dx. doi.org/10.2147/JMDH.S93680

16. Loeys BL, Dietz HC, Braverman AC, Callewaert BL, De Backer J, Devereux RB, et al. The revised Ghent nosology for the Marfan syndrome. J Med Genet. 2010;47(7):476-85. http:// dx.doi.org/10.1136/jmg.2009.072785

17. Sateia MJ. International classification of sleep disordersthird edition: highlights and modifications. Chest. 2014;146(5):1387-1394. http://dx.doi.org/10.1378/chest.1 4-0970

18. Xie C, Zhu R, Tian Y, Wang K. Association of obstructive sleep apnoea with the risk of vascular outcomes and all-cause mortality: a meta-analysis. BMJ Open. 2017; 7:e013983. http://dx.doi.org/10.1136/bmjopen-2016-013983

19. Neuville M, Jondeau G, Crestani B, Taillé C. Respiratory manifestations of Marfan's syndrome. Rev Mal Respir. 2015;32(2):173-81. http://dx.doi.org/10.1016/j.rmr.2014.06. 030

20. Cistulli PA, Sullivan CE. Sleep apnea in Marfan's syndrome. Increased upper airway collapsibility during sleep. Chest. 1995; 108(3):631-635. https://doi.org/10.1378/chest.108.3.631

21. Kohler M, Pitcher A, Blair E, Risby P, Senn O, Forfar C, et al. The impact of obstructive sleep apnea on aortic disease in Marfan's syndrome. Respiration. 2013;86(1):39-44. http://dx. doi.org/10.1159/000340008

22. Mo L, He Q, Wang Y, Dong B, He J. High prevalence of obstructive sleep apnea in Marfan's syndrome. Chin Med J (Engl). 2014;127(17):3150-5. http://dx.doi.org/10.3760/cma.j. issn.0366-6999.20140660

23. Faivre L, Collod-Beroud G, Child A, Callewaert B, Loeys BL, et al. Contribution of molecular analyses in diagnosing Marfan syndrome and type I fibrillinopathies: an international study of 1009 probands. J Med Genet. 2008; 45(6):384-390. http:// dx.doi.org/10.1136/jmg.2007.056382
24. Beighton P, de Paepe A, Danks D, Finidori G, Gedde-Dahl $T$, Goodman R, et al. International nosology of heritable disorders of connective tissue, Berlin, 1986. Am J Med Genet. 1988; 29:581-94.

25. Penpattharakul W, Pithukpakorn M. Revised Ghent Criteria is Comparable to original diagnostic criteria for marfan syndrome with increased ability to clinically diagnose related disorders. J Med Assoc Thai. 2016; 99:34-9.

26. Corsico AG, Grosso A, Tripon B, Albicini F, Gini E, Mazzetta $A$, et al. Pulmonary involvement in patients with Marfan Syndrome. Panminerva Med. 2014;56:177-82.

27. Sher AE, Schechtman KB, Piccirillo JF. The efficacy of surgical modifications of the upper airway in adults with obstructive sleep apnea syndrome. Sleep. 1996;19(2):156-77. http://dx. doi.org/10.1093/sleep/19.2.156

28. Terris DJ, Coker JF, Thomas AJ, Chavoya M. Preliminary findings from a prospective, randomized trial of two palatal operations for sleep-disordered breathing. Otolaryngol Head Neck Surg. 2002; 127(4):315-23. http://dx.doi.org/10.1067/ mhn.2002.128345

29. Naran S, Steinbacher DM, Taylor JA. Current Concepts in Orthognathic Surgery. Plast Reconstr Surg. 2018;141(6):925e-936e. http://dx.doi.org/10.1097/PRS.000 0000000004438

30. Bauss O, Sadat-Khonsari R, Fenske C, Engelke W, SchwestkaPolly R. Temporomandibular joint dysfunction in Marfan syndrome. Oral Surg Oral Med Oral Pathol Oral Radiol Endod. 2004; 97(5):592-8. http://dx.doi.org/10.1016/S1079 210403006607
Received on: 2/11/2018

Final version resubmitted on: 12/12/2018

Approved on: 5/2/2019 